\title{
Behaviors and Attitudes of Polish Health Care Workers with Respect to the Hazards from Blood-Borne Pathogens: A Questionnaire-Based Study
}

\author{
Anna Garus-Pakowska ${ }^{1, *(D)}$ and Mariusz Górajski ${ }^{2}$ (D) \\ 1 Department of Hygiene and Health Promotion; Medical University of Lodz, 90-752 Lodz, Poland \\ 2 Department of Econometrics, University of Lodz, 90-214 Lodz, Poland; mariusz.gorajski@uni.lodz.pl \\ * Correspondence: anna.garus-pakowska@umed.lodz.pl; Tel.: +48-4-2272-5288
}

Received: 30 January 2019; Accepted: 8 March 2019; Published: 12 March 2019

\begin{abstract}
Blood-borne infections represent an important occupational health issue in health care settings. The aim of this study was to analyze behaviors of health care workers (HCWs) in the field of needlestick injuries (NSIs) as well as to learn about their attitudes to patients infected with blood-borne viruses. A total of 487 HCWs based at 26 hospitals in Poland completed an anonymous self-administered questionnaire in the period of October-December 2015. Data was analyzed using descriptive statistics and multiple logistic regression. Of the HCWs, $44.8 \%$ suffered superficial wounds, and $17.9 \%$ HCWs were cut deeply at least once. The most frequent causes of injuries were: rush $(31.4 \%)$, unpredictable patient behavior $(29 \%)$, and lack of attention (27\%). The rate of underreporting NSIs was $45.2 \%$. Males showed more than three times higher chance of not reporting injuries (odds ratio (OR) 3.495, 95\% Confidence Interval (CI): 1.65-7.49). The nurses more often took off their protective gloves to make the procedure easier $(p=0.036)$. Taking off protective clothes was positively associated with long work experience (OR 1.16, 95\% CI: 0.995-1.36). Recapping concerned $15.5 \%$ of doctors, $8.2 \%$ of nurses, and $11.2 \%$ of paramedics. $25.9 \%$ HCWs feared infection in the workplace, and every tenth HCW refused to help the infected patient. The longer the work experience, the greater the concern about the possibility of infection (OR 1.33, 95\% CI: 0.99-1.78). Most HCWs were more cautious when dealing with an infected patient and in their opinion infected patients should be required to inform HCWs of their serological status and such information should be compulsorily transferred between different health institutions. The emphasis in the training of HCWs in the future should be on classes perfecting practical skills like paying more attention to reporting NSIs, improving occupational behaviors like avoiding needle recapping, and on the development of appropriate attitudes towards patients infected with HIV, HBV, or HCV.
\end{abstract}

Keywords: needlestick injuries; sharp injury; health care workers; occupational exposure; risk factors; knowledge; behaviors; underreporting; hospitals; Poland

\section{Introduction}

Among the more than 60 different pathogens transmitted through the bloodstream, and thus threatening workers in health care settings hepatitis B virus (HBV), hepatitis C virus (HCV), and human immunodeficiency virus (HIV) are the most common and carry a serious risk of complications. They also cause social consequences, such as stigma and discrimination, and economic consequences associated with diagnostics and treatment [1-5]. The risk of infection of the exposed person (from a single needlestick injury-NSI, by a contaminated needle) is estimated to range between $10-30 \%$ for HBV [6], 1.8-10\% for HCV [7], and 0.3\% for HIV infection [8]. WHO reports in the World Health 
Report 2002, that of the 35 million health-care workers, 2 million experience percutaneous exposure to infectious diseases each year. It further notes that $37.6 \%$ of Hepatitis B, 39\% of Hepatitis C and $4.4 \%$ of HIV / AIDS in health care workers (HCWs) around the world are due to needlestick injuries (NSI) [9].

In Poland, there is no surveillance system regarding needlestick and sharp injuries (NSIs) but in the structure of infectious and parasitic occupational diseases among health care and social workers $\mathrm{HBV}, \mathrm{HCV}$, and Tuberculosis are the most common [10]. Tuberculosis is spread from person to person through the air but cases of blood-borne infection from NSI are also described [11]. It is important that in the epidemic chain HCW may be at risk of infection, but infected-HCW can be a source of infection for the patient [12]. Therefore, it is important to take all actions to prevent injuries to medical personnel. For this purpose, first in this manuscript, prevalence of NSIs and risk factors will be identified. Literature describes such NSIs risk factors as age, short work experience, long working hours and working in surgical or intensive care units [13]. Knowledge of the risk of infection, routes of transmission, and possible prevention is an important aspect in the development of appropriate behavior of HCWs in response to exposure to infectious material.

In psychology, the theories of reasoned action and planned behavior represent connect beliefs with behavior [14]. In accordance with the theory of reasoned action, the best basis for predicting planned behaviors is the attitudes of people towards a particular behavior and their subjective norms (SN), the behavioral intention and behavior are created from these two aspects. Subjective norms, that is, people's beliefs about how others, whose opinion matters, will react to this behavior, are a very important factor. If we want to make someone happy, we will do something even against our normal attitudes. To increase the prognostic power of the theory Ajzen introduced a ratio of perceived behavioral control as a third determinants of behavior intentions. The theory of planned behavior assumes that perceived behavioral control is an entity's ease or difficulty in achieving a particular behavior [15]. Understanding these three elements allows us to well predict the behavioral intentions of others that are highly correlated with their planned behaviors.

In this paper we do not study the actual psychological mechanisms leading to behaviors of HCWs, but we simply apply the random utility theory which is based on the hypothesis that every individual is a rational decision-maker, maximizing utility relative to his or her choices [16]. In our study, we described 4 improper or harmful behaviors of HCWs: taking off protective clothing $\left(t c_{i}\right)$, no participation in trainings $\left(n t_{i}\right)$, lack of NSIs reporting $\left(l r_{i}\right)$, and recapping $\left(r e_{i}\right)$. Furthermore, we look for determinants of the following $4 \mathrm{HCWs}$ attitudes to patients infected with blood-borne viruses: fear of infection $\left(f s_{i}\right)$, long-term fear $\left(f l_{i}\right)$, needs of introducing an information system about infected patients $\left(i s_{i}\right)$, and indifference $\left(i n_{i}\right)$.

A number of strategies are available for avoiding the disease burden associated with NSIs, including vaccination against $\mathrm{HBV}$, post-exposure prophylaxis, reducing the number of injections and invasive procedures where appropriate, using safer devices and properly disposing of needles and other sharps [9]. Access to personal protective equipment, such as gloves, gowns, masks etc. and hand washing are non-specific methods of protection against many infectious diseases, and the described negligence in this area remind us of the constant need for training [17]. In our study we would like to draw attention to such negative behaviors as removing protective gloves while doing work at the patient, or putting on the covers for used needles.

The aim of the study was to analyze behaviors of HCWs in the field of needlestick injuries as well as to learn about their attitudes to patients infected with blood-borne viruses. We estimated the impact of knowledge on the behaviors and attitudes of HCWs. Additionally, we rated the frequency of contact of the HCWs with blood and other body fluids, circumstances that may have contributed to the injury (risk factors), and the NSIs reporting.

\section{Materials and Methods}

The present work is part of the study on exposure to infectious material of HCWs in Poland. In 2015, we sent inquiries - surveys to all hospitals in Poland ( $N=956$, as of 31 December 2014) to 
collect registry data on HCWs NSIs. As many as 252 hospitals sent us official register data (return index $=26.36 \%$ ). Representing a total annual average of 28,051 physicians, 64,806 nurses /midwifes and 3449 paramedics. We selected $26(10 \%)$ of these hospitals to which we sent a questionnaire in electronic form. It was a selection based on the accessibility of the respondents (courtesy, cooperation and interest of the management of hospitals). The survey was for volunteer HCWs so we did not calculate the return index. 487 completed questionnaires were returned correctly. Thus, the study was conducted in 26 selected hospitals in the period of October-December 2015 from which we obtained 487 surveys.

The hospitals were located in urban communes and in urban-rural communes. In Poland, the commune is the basic unit of local self-government. The urban commune is a community located in a city. The urban-rural commune consists of a city that is the seat of the commune authorities and the surrounding villages.

A self-administered questionnaire was designed to assess HCW's knowledge, behaviors and attitudes towards hand hygiene and needlestick injuries.

Regarding knowledge a short test was included focusing on five statements, to which possible answers were: "true", "false" or "I do not know". The following questions asked were:

Q1. Hand disinfection can be replaced by the use of protective gloves.

Q2. In an emergency situation, the disinfection of hands is not required.

Q3. Approximately $60 \%$ of HBV infections among adults in Poland are nosocomial.

Q4. In the case of a single puncture by used needle, it is easier to become infected with HIV than HBV.

Q5. Tuberculosis infection is possible only by droplets.

The answers to the above questions constitute five independent variables, which measure the level of HCW's knowledge. We also aggregated the results of knowledge that defined the overall knowledge variable classified as poor (less than 3 corrected answers), fair ( 3 corrected answers) and good (more than 3 corrected answers). In addition, we asked about the sources of knowledge and about participation in training on post-exposure proceedings.

Regarding behaviors, we asked how often personal protection equipment is used; has it happened that the HCW had removed protective clothing (e.g., gloves) to perform the operation "more easily" with the patient; we also asked about the recapping of used needles and the reporting of NSIs.

In terms of attitudes, we asked HCWs about the fear of infection in the workplace and also about changing their own behavior under the influence of awareness of care for an infected patient. We analyzed HCWs opinions on the obligation to provide information about infected patients. We also evaluated the feelings of HCWs after NSIs. In the questionnaire the variable "soon forgot about it" meant that the HCW who had been hurt was able to do his/her job further. And the variable "felt a long-lasting fear" meant that the HCW who had been hurt interrupted his/her work on the day of the risky event, "was paralyzed", and could not continue to "work" normally, s/he was thinking about a possible threat all the time.

To assess the frequency of exposure to infectious material in the workplace, we asked about the occupational exposure which occurred in the 12 months preceding the survey. Occupational exposure to blood-borne pathogens among HCWs includes percutaneous exposures to needles and other sharp objects, and mucocutaneous exposure (i.e., contact with intact or nonintact skin, and contact with mucous membranes) [18]. In this study "superficial wounds" were defined as "loss of epidermis only" and "deep cuts" were defined as "damage to deeper tissues like tendons, muscles, ligaments, nerves, blood vessels, or bones". In addition, we examined the circumstances that, according to the respondents, contributed to the injury.

The reliability and validity of the survey was assessed on the basis of previous studies [19].

In the present analysis, the following sociodemographic measures were taken into account: gender, job category, work experience (in years), and place of employment (urban commune or rural and urban commune). 


\section{Statistical Analysis}

We assessed the degree of association between pairs of variables by presenting contingency tables in the first line, and we applied classical Fisher's Exact test for count data and Pearson's Chi-squared test of independence. Moreover, we used Goodman and Kruskal's gamma to measure the strength of association when both variables were measured at the ordinal scale, and for nominal variables, we calculated contingency coefficients.

The above mentioned behaviors ( 4 dependent variables) and attitudes (4 dependent variables) of HCWs were measured by simultaneous observation of dichotomous categorical variables received from the self-administered questionnaire. The values of each dependent variable falls into one of two categories, "Yes, I confirm this behavior/attitude" or "No, I do not confirm this behavior/attitude". To determine the main drivers (factors) of healthcare workers' behaviors and attitudes for each indicator variable we performed logistic regression with the following 6 explanatory (controls) variables: job category ( $j b_{i}$ with 3 categories: doctors, nurses or paramedics), gender $\left(g_{i}\right)$, work experience ( $\exp _{i}$ with 4 categories: less than $5,6-15,16-25,>25$ years), and place of employment ( emp $_{i}$ with 2 categories: urban commune or rural and urban commune), personal situation ( $p s_{i}$ with 2 categories: I feel insecure at my workplace " or "I am professionally fulfilled") and the overall knowledge of worker ( $k n_{i}$, with 3 categories poor, fair and good). For a given worker $i$, let $y_{i}$ be a dichotomous variable describing his/her particular behavior or attitude i.e., $y_{i} \in\left\{t c_{i}, n t_{i}, l r_{i}, r e_{i}\right\} \cup\left\{f s_{i}, f l_{i}, i s_{i}, i n_{i}\right\}$, and let $U_{y_{i}}$ be the internal utility that worker $i$ obtains from this behavior or attitude. The utility gains are given by $U_{y_{i}}=\beta_{0}+\beta^{\prime} x_{i}+\epsilon_{i}$ and depends on the above listed characteristics of the worker and her place of employment grouped into a vector $x_{i}=\left[j b_{i}, g_{i}, \exp _{i}, k n i\right.$, pemp $\left.p_{i}, p s_{i}\right]$, where the unobserved term, $\epsilon_{i}$, is random shock with logistic distribution. The HCW $i$ takes the attitude or behavior $\left(y_{i}=1\right)$ if $U_{y_{i}}>0$ and do not if $U_{y_{i}}<0$. The conditional probability of $y_{i}=1$ is given by $\operatorname{Pr}\left(y_{i}=1 \mid x_{i}\right)=\frac{1}{1+e^{-\beta_{0}-\beta^{\prime} x_{i}}}$.

To find the best model we performed the best subset regression algorithm and fitted a separate logistic regression for each possible combination of the $k=1,2,3,4,5,6$ predictors. We then look at all of the resulting models and identified the one that is best using the following rule: all predictors in the model are statistically significant and the value of the Akaike Information Criterion is minimized. To assess the influence of control variables on behaviors and attitudes we calculated the odds ratios.

The statistical computations were performed using R statistical software and Excel. The level of statistical significance was set at $p<0.05$. The study protocol was approved by the Bioethics Committee of the Medical University of Lodz (Document No. RNN /163/14/KB of 11.02.2014).

\section{Results}

\subsection{Characteristics of the Study Group}

A total of $487 \mathrm{HCWs}$ filled the questionnaire. About half of the study participants were female $(56.9 \%), 44 \%$ of them were paramedics and $40 \%$ were nurses, and $31.4 \%$ had less than 5 years of employment. There was approximately an equal distribution among hospitals located in urban commune (44\%) and rural/urban commune (55\%), Table 1. 
Table 1. Demographic characteristics of health care workers, $N=487(\%)$.

\begin{tabular}{ccc}
\hline \multicolumn{2}{c}{ Demographic Characteristics } & Number (\%) \\
\hline Gender & Male & $210(43.1)$ \\
& Female & $277(56.9)$ \\
\hline Job Category & Doctors & $76(15.60)$ \\
& Nurses & $196(40.25)$ \\
& Paramedics & $215(44.15)$ \\
\hline Work Experience (in years) & $<5$ & $153(31.4)$ \\
& $5-15$ & $128(26.3)$ \\
& $16-25$ & $89(18.3)$ \\
Place of employment & $>25$ & $117(24.0)$ \\
& Urban commune & $215(44.15)$ \\
& Rural and urban commune & $272(55.85)$ \\
\hline
\end{tabular}

\subsection{Frequency and Circumstances of Injuries}

During the 12 months preceding the study, most doctors, nurses and paramedics were in contact with the infectious material through intact skin. They had less contact through damaged skin, mucous membranes and splattering onto conjunctiva. Almost every second HCW (44.8\%) suffered superficial wounds, and almost every fifth HCW (17.9\%) had been cut deeply at least once. More often, both the superficial and deep injuries were among nurses (respectively to the second and every fourth) $(p<0.05)$, Table 2. The most frequent causes of injuries were: rush $(31.4 \%)$, unpredictable patient behavior $(29 \%)$, lack of attention $(27 \%)$, stressful situation requiring urgent intervention such as sudden hemorrhage or collapse $(16.3 \%)$, as well as too high workload $(14.3 \%)$.

Table 2. Frequency of health care workers (HCWs) contacts with potentially infectious material within 12 months preceding the study.

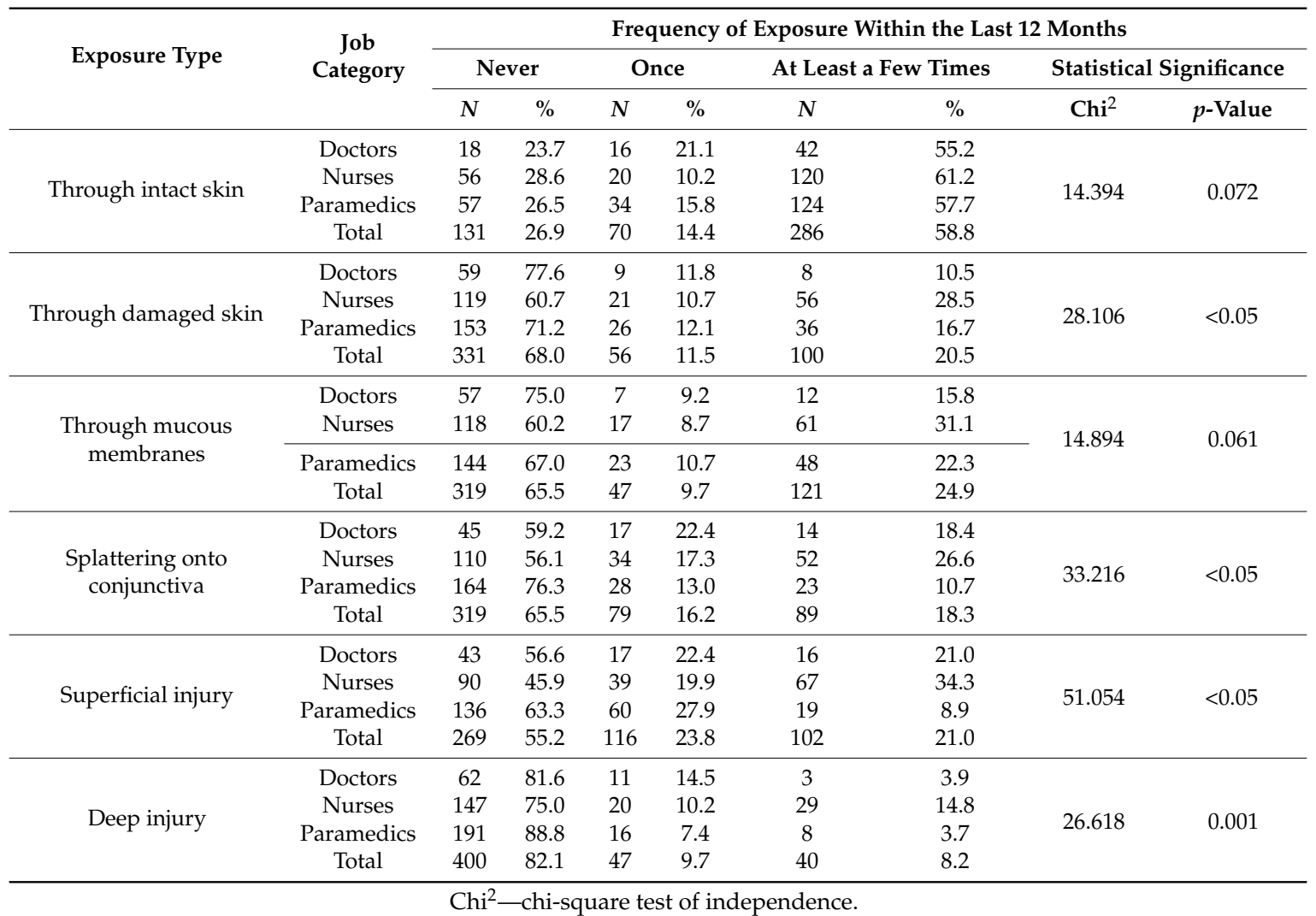




\subsection{Knowledge, Behaviors, and Attitudes}

The correct answers to all five questions from the knowledge test were given by 25 doctors ( $32.9 \%)$, 34 paramedics (15.8\%) and 18 nurses $(9.2 \%)$. The most common were 4 correct answers (doctors: $n=31$, $40.8 \%$, nurses: $n=63,32.1 \%$, paramedics: $n=85,39.5 \%$ ). We rated the level of knowledge as poor for $15 \%$ of HCWs, fair for $31 \%$ of HCWs, and good for $54 \%$ of HCWs.

The distribution of correct answers to individual questions is given in Table 3. The frequency of providing correct answers did not depend on the sex, seniority, or location of the hospital. Q3, Q4, and Q5 questions were more often answered correctly by doctors $(p<0.05)$, Table 3.

Table 3. Distribution of the responses provided by the HCWs during the test of knowledge.

\begin{tabular}{|c|c|c|c|c|c|c|c|c|c|c|}
\hline \multirow{3}{*}{ Question } & \multicolumn{10}{|c|}{ Correct answer $N(\%)$} \\
\hline & \multicolumn{2}{|c|}{ Doctors } & \multicolumn{2}{|c|}{ Nurses } & \multicolumn{2}{|c|}{ Paramedics } & \multicolumn{2}{|c|}{ Total } & \multicolumn{2}{|c|}{$\begin{array}{c}\text { Statistical } \\
\text { Significance }\end{array}$} \\
\hline & $N$ & $\%$ & $N$ & $\%$ & $N$ & $\%$ & $N$ & $\%$ & $\mathrm{Chi}^{2}$ & $p$-Value \\
\hline $\begin{array}{l}\text { Q1. Can use of gloves } \\
\text { replace disinfection of } \\
\text { hands? }\end{array}$ & 73 & 96.05 & 188 & 95.92 & 210 & 97.67 & 471 & 96.72 & 1.12 & 0.57 \\
\hline $\begin{array}{l}\text { Q2. Is disinfection of hands } \\
\text { necessary in emergency } \\
\text { situations? }\end{array}$ & 51 & 67.11 & 119 & 60.71 & 146 & 67.91 & 316 & 64.89 & 2.52 & 0.28 \\
\hline $\begin{array}{l}\text { Q3. Do you agree that } 60 \% \text { of } \\
\text { HBV infections in Poland is } \\
\text { connected with health care? }\end{array}$ & 56 & 73.68 & 112 & 57.14 & 143 & 66.51 & 311 & 63.86 & 7.66 & 0.02 \\
\hline $\begin{array}{l}\text { Q4. Is it more likely to } \\
\text { become infected with HIV } \\
\text { than with HBV as a result of } \\
\text { single needlestick injury with } \\
\text { a contaminated needle? }\end{array}$ & 71 & 93.42 & 154 & 78.57 & 169 & 78.61 & 394 & 80.90 & 9.13 & 0.01 \\
\hline $\begin{array}{l}\text { Q5. Is infection with } \\
\text { tubercule bacillus possible } \\
\text { solely through droplet } \\
\text { infection? }\end{array}$ & 57 & 75 & 62 & 31.63 & 95 & 44.19 & 214 & 43.94 & 41.82 & 0.00 \\
\hline
\end{tabular}

Among the 487 respondents, the majority of HCWs $79.5 \%(n=387)$ felt the need to increase knowledge about the possibility of getting infected in the workplace. However, simultaneously as many as $82.1 \%$ of HCWs responded that their knowledge was gained during the basic training (school/study). 68.6\% HCWs participated in various refresher courses, but only less than every second $(45.6 \%)$ read scientific journals. Nurses most often participated in the trainings ( $\mathrm{chi}^{2}=36.813, p<0.05$ ). For example, $25 \%$ of doctors, $22.8 \%$ of rescuers, and $10.2 \%$ of nurses never participated in the training on post-exposure proceedings.

Regarding behaviors, most HCWs used personal protective equipment such as clothes and protective gloves. Only $3.7 \%$ of employees answered that they never use protective gloves, $10.1 \%$ protective gowns, and $49.8 \%$ goggles or other face shields. However, it should be remembered that not all activities performed on the patient require the use of protective clothing. At the same time, a large number of respondents admitted that they took off protective clothing (e.g., gloves) to perform an activity "more easily" on the patient (doctors: $N=33,43.4 \%$; nurses: $n=116,59.2 \%$; paramedics: $N=111,48.4 \%)$. This answer was the most common among nurses ( $p=0.036)$.

On average, every tenth HCW $(11.7 \%)$ was spotted for improper handling of used needles. Recapping concerned $15.5 \%$ of doctors $(n=12), 8.2 \%$ of nurses $(n=16)$ and $11.2 \%$ of paramedics 
$(n=24)$. Among them, when placing the cover on the contaminated needle, 2 doctors, 4 nurses and 4 paramedics were injured.

Most HCWs $(n=440,90.3 \%)$ answered that they had always reported the fact of injury to the appropriate person responsible for keeping the register. Most often they were nurses $(92.3 \%)$ and paramedics $(93.5 \%)(p<0.01)$. However, when asked about reporting the last NSIs that occurred in the last 12 months preceding the study, only $54.8 \%$ of HCWs reported this fact. The other half of incidents $(45.2 \%)$ have not been reported anywhere. The main reason for not reporting the sharp injuries was the perception that there was no such need. The variables such as seniority, place of employment and knowledge did not have any significant impact on the attendance.

Regarding attitudes, every fourth HCWs (25.9\%) feared infection in the workplace. Nurses had the most concerns $(37.2 \%, p<0.01)$, women $(31.0 \%, p<0.01)$, and HCWs with the shortest work experience $(31.4 \%, p<0.01)$. After the last injury, $35.2 \%$ of HCWs felt fear/anxiety but soon forgot about it. However, $16.3 \%$ of HCWs felt a long-term fear for their own health. Every third HCW $(30.8 \%)$ did not feel anything special, arguing that NSIs are an inseparable part of the work of medical personnel. A small percentage of HCWs (5.3\% doctors, $6.6 \%$ nurses and $1.4 \%$ paramedics) did not exercise greater caution in dealing with a patient known to be infected with HIV, HBV, or HCV. HCWs with shorter work experience mostly changed their behavior $(83 \%$ from $<5$ years work experience and $78.9 \%$ HCWs from $6-15$ years of work experience, $p=0.002$ ). The HCWs from rural-urban communes changed their attitudes more often $(p=0.052) .93 .4 \%$ of nurses, $89.5 \%$ of doctors and $87.0 \%$ of paramedics have never refused to perform the examination, surgery, or care of a patient with an infection. However, the others feared personal infection and they refused to help the infected patient at least once. Most HCWs (69.4\%) would like patients to be required to inform medical personnel that they are infected with blood-borne viruses. Even more HCWs (78.2\%) see the need to introduce in Poland an obligatory system of transmitting information about infected patients between different health care units (throughout the health care service system).

\subsection{The Influence of Knowledge and Other Variables on Behaviors and Attitudes}

Multivariate logistic regression analysis of the odds (OR) for behaviors and attitudes in relation to the potential risk factors listed above is presented in Table 4 .

Regarding behaviors, taking off protective clothes to make it "easier" to take action with the patient was positively associated with long work experience (odds ratio (OR) 1.16, 95\% confidence interval (95\% CI): 0.995-1.36), and negatively associated with knowledge (OR 0.75, 95\% CI: 0.58-0.96). Recapping was positively associated with knowledge (OR 7.74, 95\% CI: 1.70-13.15), and negatively associated with job category (OR $0.15,95 \%$ CI: $0.01-0.78$ ) and place of employment (OR $0.21,95 \%$ CI: 0.05-0.73). Males showed more than three times higher chance of not reporting injuries (OR 3.495, 95\% CI: $1.65-7.49)$.

Regarding attitudes none of the variables significantly affected the possibility of refusing treatment/care to an infected patient. Concern about the possibility of getting infected in the workplace was positively associated with long work experience (OR 1.33, 95\% CI: 0.99-1.78). Long-term fear after NSIs was also positively associated with knowledge (OR 2.28, 95\% CI: 1.29-4.43). Males were less likely to experience such long-term fear (OR 0.38, 95\% CI: 0.13-1.12). 
Table 4. Multivariate logistic regression analysis of odds ratio (OR) for behaviors and attitudes of HCWs in relation to potential risk factors.

\begin{tabular}{|c|c|c|c|c|c|c|c|c|}
\hline \multirow{3}{*}{ Variables } & \multicolumn{8}{|c|}{ Odds Ratios with $95 \%$ Confidence Interval (CI) from Logistic Regression Models } \\
\hline & \multicolumn{4}{|c|}{ Behaviors, OR (95\% CI) } & \multicolumn{4}{|c|}{ Attitudes, OR (95\% CI) } \\
\hline & $\begin{array}{c}\text { No } \\
\text { Participation in } \\
\text { Trainings }\end{array}$ & $\begin{array}{l}\text { Removing Protective } \\
\text { Clothing to "Make It } \\
\text { Easier" to Perform the } \\
\text { Action at the Patient }\end{array}$ & Recapping & $\begin{array}{l}\text { Lack of NSIs } \\
\text { Reporting }\end{array}$ & $\begin{array}{c}\text { Fear of } \\
\text { Infection in the } \\
\text { Workplace }\end{array}$ & $\begin{array}{c}\text { After NSIs, I } \\
\text { Did Not Feel } \\
\text { Anything } \\
\text { Special }\end{array}$ & $\begin{array}{l}\text { Long-Term Fear } \\
\text { for Their Own } \\
\text { Health After } \\
\text { NSIs }\end{array}$ & $\begin{array}{l}\text { The Need to Introduce } \\
\text { an Information } \\
\text { System About } \\
\text { Infected Patients }\end{array}$ \\
\hline $\begin{array}{l}\text { Job category } \\
\text { (nurses) }\end{array}$ & $\begin{array}{l}0.465 \text { ** (1) } \\
(0.22-1.01) \\
\end{array}$ & - & $\begin{array}{c}0.145 *(2) \\
(0.01-0.78)\end{array}$ & - & $\begin{array}{l}2.929 * * *(1) \\
(1.35-6.35)\end{array}$ & - & $\begin{array}{c}4.040 *(1) \\
(0.99-27.67)\end{array}$ & - \\
\hline $\begin{array}{l}\text { Job category } \\
\text { (paramedics) }\end{array}$ & $\begin{array}{l}0.585^{* *}(1) \\
(0.31-1.14) \\
\end{array}$ & - & - & $\begin{array}{l}0.241^{* * *(2)} \\
(0.11-0.53)\end{array}$ & $\begin{array}{l}2.639 * * *(1) \\
(1.28-5.41)\end{array}$ & - & $\begin{array}{c}7.158 * *(1) \\
(1.83-48.25)\end{array}$ & $\begin{array}{l}2.849^{* * * *(2)} \\
(1.78-4.68)\end{array}$ \\
\hline Gender (Male) & - & - & - & $\begin{array}{c}3.495 * * * \\
(1.65-7.49) \\
\end{array}$ & $\begin{array}{c}2.095^{* *} \\
(1.08-4.09) \\
\end{array}$ & - & $\begin{array}{c}0.378^{*} \\
(0.13-1.12) \\
\end{array}$ & - \\
\hline $\begin{array}{l}\text { Work } \\
\text { experience } \\
\text { (increasing } \\
\text { seniority) }\end{array}$ & $\begin{array}{c}0.621^{* * *} \\
(0.46-0.82)\end{array}$ & $\begin{array}{c}1.163 * \\
(0.99-1.36)\end{array}$ & - & - & $\begin{array}{c}1.327^{*} \\
(0.99-1.78)\end{array}$ & - & - & - \\
\hline $\begin{array}{c}\text { Place of } \\
\text { employment } \\
\text { (rural and urban } \\
\text { commune) }\end{array}$ & - & - & $\begin{array}{c}0.209 * * \\
(0.05-0.73)\end{array}$ & - & - & - & - & $\begin{array}{c}0.679 * \\
(0.43-1.06)\end{array}$ \\
\hline $\begin{array}{l}\text { Personal } \\
\text { situation (I am } \\
\text { professionally } \\
\text { fulfilled) }\end{array}$ & $\begin{array}{c}0.506^{* * *} \\
(0.309,0.826)\end{array}$ & - & - & - & $\begin{array}{c}0.482^{* *} \\
(0.251,0.878)\end{array}$ & $\begin{array}{c}2.858^{* * *} \\
(1.485,5.839)\end{array}$ & & \\
\hline $\begin{array}{c}\text { Knowledge } \\
\text { (increasing level } \\
\text { of knowledge) }\end{array}$ & - & $\begin{array}{c}0.747^{* *} \\
(0.58-0.96)\end{array}$ & $\begin{array}{c}7.74 * * \\
(1.70-13.72)\end{array}$ & - & - & $\begin{array}{c}0.717 * \\
(0.48-1.06)\end{array}$ & $\begin{array}{c}2.281 * * * \\
(1.29-4.43)\end{array}$ & - \\
\hline
\end{tabular}

Note: ${ }^{*} p<0.1 ;{ }^{* *} p<0.05 ;{ }^{* * *} p<0.01 ;(1)$ ref. $=$ doctors; (2) ref. $=$ others. 


\section{Discussion}

Health care workers are at common risk of occupational exposure to blood and other potential infectious material. In the study Martins et al. $65 \%$ of employees of a selected hospital in Portugal reported having experienced at least one NSSI in the last 5 years [20]. Most of the events, similar to ours and other studies (Polish and international) [21-25] concerned nurses. It should be noted that nurses are the most numerous professional group among medical employees, they perform the most treatments and usually have direct contact with patients.

The risk of acquiring the blood-borne diseases through occupational exposure depends on the number of injuries, prevalence of BB infections in the patient population and probability of a percutaneous injury transmitting blood-borne viruses [26]. With increasing rate of national and international hepatitis $\mathrm{B}$, hepatitis $\mathrm{C}$, and HIV these are risks that HCWs cannot afford to take. In our study perceived causes of injury were: rush (31.4\%), unpredictable patient's behavior (29\%), and lack of attention (27\%). In the study by Salzer et al. [27] time pressure and lack of experience were the most frequent causes of NSIs, while in other studies the main reason for occupational exposure was a sudden movement of the patient during the procedure [28]. The same reasons as in our study were obtained by Bećirević et al.: being in rush, patient's unpredictable reaction and decrease in concentration [29].

The knowledge of medical personnel should be considered insufficient. The level of knowledge of HCWs has been the subject of many studies but little is known about whether knowledge/lack of knowledge about the possible risk of infection can affect behaviors/attitudes [22,30]. In our study nurses showed the weakest knowledge. Interestingly, nurses most often participated in trainings and the least often presented negative behaviors in the recapping. At the same time, they usually took off their protective clothing to perform some procedures on the patient. Most often, they also reported NSIs. In our opinion, negative behavior may have resulted from the nature of the work rather than from lack of knowledge. Nurses have the most frequent contact with the patient, they are more likely to perform invasive procedures, so they will also have the biggest chance to remove protective clothing, e.g., protective gloves to "facilitate" their work. Such behaviors may result from excessive workload, in a hurry, and these HCWs risk factors have been indicated as the most common causes of injury. The training deals with the subject of recapping, and almost always reminds us of the obligation to report injuries. In this matter, knowledge influenced the improvement of behavior.

This study revealed that information on $45.2 \%$ of injuries was not entered into an official register. This is close to the results of some studies (i.e., $51 \%$ in the survey by Makary et al.) [31], but less than in others (i.e., $66.1 \%$ in the study by Cui et al. and $60.2 \%$ in the study by Jahangiri et al.) [32,33]. Most common reason for failure to report the incidents of NSIs were lack of time and heavy clinical schedule, as well as perception of low risk of infection $[33,34]$ which is close to our results, in which part of HCWs in its own assessment did not see the need to report NSIs. This is still a gap for enhanced training. HCWs should be aware that reporting an injury is highly important and adjust their behavior accordingly.

Medical personnel suffer from anxiety and emotional distress following NSIs [35]. In our study, logistic regression showed that people with better knowledge are more afraid of their own health after being hurt and this fear lasted longer. The reason is unclear, but it may be related to the fact that people with better knowledge are aware of the possible dangers of wounds contaminated with a needle. However, the long-term fear was also positively correlated with the practice of nurse and rescuer, who at the same time showed lower knowledge in the knowledge test. In these cases, the fear may be due to the generally more frequent contacts of employees of these professions with infectious material. One should also take into account the possibility that the measurement of knowledge was imprecise because the test of knowledge covered only 5 questions. Probably fear for one's own health may affect better wound reporting in the paramedics and nurses group. Men in our study were less afraid, and at the same time reported less frequent incidents of injuries. Similarly, with doctors. It is quite understandable when we are not afraid of something, we do not see the need to report. In the research by Jahić et al. also physicians were significantly less likely to report exposure incidents 
than other staff [36]. The vast majority of HCWs are more cautious when dealing with an infected patient. Fortunately, the cases of refusal to provide assistance to patients infected with HBV, HCV, or HIV were rare, and were not subject to any risk factors. These are results similar to Ishimaru et al. in which the majority of nurses expressed a willingness to care for patients infected with HIV, HBV or HCV [37].

One of the major alarming observations in the current study is that most HCWs believed that patients with HIV should be required to inform physicians of their status. Moreover, they think that such information should be compulsorily transferred between different health institutions. In another Polish study, Gańczak et al. found insufficient knowledge of hospital staff in surgical wards, in which $40 \%$ of HCWs were in favor of moving away from performing surgical procedures if the HCW was infected with HBV or HCV, and $42.6 \%$ with respect to HIV infected HCWs. In the same research 16.2\% HCWs stated that infected surgeons should disclose their HBV, HCV, or HIV serostatus [38]. HCWs should be aware of the risks, but above all they should have knowledge about prevention methods that effectively protect against infection. Although HBV infection can be prevented by vaccination, there is no effective vaccine for $\mathrm{HCV}$ and HIV. Before other infections, strict compliance with the universal precautions is important. In our study the vast majority of the HCWs were afraid of being infected during work, and almost all admitted that they performed medical procedures more carefully with patients they knew to be infected with HIV, HBV, or HCV. This may indicate a lack of awareness that absolutely every patient should be treated as a potential source of infection. The use of personal protective equipment for operations performed on the patient and carefully carrying out all procedures should not be dependent on the results of the patient's tests for markers of blood-borne virus infections, due to the possibility of patients being in the serological window or low sensitivity of the tests. The patient himself is not obliged to inform that he/she is infected; therefore, in a job where there is a possibility of contact with potentially infectious material, the same safety precautions must be used for all patients.

HCWs' knowledge about blood-borne infections and their prevention (hand hygiene) is insufficient but in our opinion, most behaviors and attitudes depended more on the type of profession than on knowledge. Better knowledge did not influence all behaviors; doctors showed better knowledge and this affected a smaller feeling of fear and less frequent NSIs reporting. Changing behavior and attitudes under the influence of the awareness of care for an infected patient is a sign of fear, which is also mentioned by the HCWs themselves. Knowledge did not significantly change these attitudes. Perhaps this is due to the fact of textbook teaching in the Polish education system. This justifies the poorer result of the knowledge test among nurses despite the relatively more frequent participation in training. Perhaps the courses and practical experience gained contribute to better nurse behavior, for example recapping. This issue requires more in-depth research. It can also imply for decision makers on medical education the need to move from theoretical instruction to the emphasis on practice. We look forward to wide participation in this discussion.

\section{Limitations}

Due to the number of surveys we have obtained, we can not generalize results for the whole country, and the entire population of hospital HCWs. Also the measure of knowledge may be imprecise due to the small number of questions in the test. This issue requires further research. For example, the test of knowledge could be extended with questions carefully checking whether the respondent knows what to do after the exposure, or whether he knows what health risks can result from this exposure.

\section{Conclusions}

The emphasis in the training of HCWs in the future should be on classes perfecting practical skills like paying more attention to reporting NSIs, improving occupational behaviors like avoiding needle recapping, and on the development of appropriate attitudes towards patients infected with HIV, HBV, or HCV in Poland, as elsewhere. 
Author Contributions: A.G.-P. conceived and designed the study and developed a research tool; M.G. was responsible for the statistical analysis of the results; A.G.-P. analyzed the data, searched the literature and wrote the paper. All authors approved the final manuscript for publication.

Funding: This research received no external funding.

Acknowledgments: Work financed by Medical University of Łódź from the own activities of a scientific unit under No. 503/6-024-01/503-61-001-18. The authors wish to thank the Hospital Directors, Healthcare Workers and Mr Andrzej Olczyk for their help in the data collection.

Conflicts of Interest: The authors declare no conflict of interest.

\section{References}

1. Tarantola, A.; Abiteboul, D.; Rachline, A. Infection risks following accidental exposure to blood or body fluids in health care workers: A review of pathogens transmitted in published cases. Am. J. Infect. Control. 2006, 34, 367-375. [CrossRef]

2. Gómez-Moreno, A.; Garaigorta, U. Hepatitis B virus and DNA damage response: Interactions and consequences for the infection. Viruses 2017, 9, 304. [CrossRef] [PubMed]

3. Zoulim, F.; Chevallier, M.; Maynard, M.; Trepo, C. Clinical consequences of hepatitis C virus infection. Rev. Med. Virol. 2003, 13, 57-68. [CrossRef]

4. Taraphdar, P.; Guha, R.T.; Haldar, D.; Chatterjee, A.; Dasgupta, A.; Saha, B.; Mallik, S. Socioeconomic consequences of HIV/AIDS in the family system. Niger. Med. J. 2011, 52, 250-253. [CrossRef] [PubMed]

5. Saia, M.; Hofmann, F.; Sharman, J.; Abiteboul, D.; Campins, M.; Burkowitz, J.; Choe, Y.; Kavanagh, S. Needlestick injuries: Incidence and cost in the United States, United Kingdom, Germany, France, Italy, and Spain. Biomed. Int. 2010, 1, 41-49.

6. Mullan, R.J.; Baker, E.L.; Hughes, J.M.; Bell, D.M.; Jaffe, H.W.; Bond, W.W.; Kane, M.A., Jr.; Chamberland, M.C.; Marcus, R.; Favero, M.S.; et al. Centers for disease control and prevention: guidelines for prevention of transmission of human immunodeficiency virus and hepatitis B virus to health-care and public-safety workers. MMWR Morb. Mortal. Wkly. Rep. 1989, 38, 1-37.

7. Centers for Disease Control and Prevention. Recommendations for prevention and control of hepatitis $\mathrm{C}$ virus (HCV) infection and HCV-related chronic disease. MMWR Morb. Mortal. Wkly. Rep. 1998, 47, 1-39.

8. Beltrami, E.M.; Williams, I.T.; Shapiro, C.N.; Chamberland, M.E. Risk and management of blood-borne infections in health care workers. Clin. Microbiol. Rev. 2000, 13, 385-407. [CrossRef]

9. Rapiti, E.; Prüss-Üstün, A.; Hutin, Y. Sharps Injuries: Assessing the Burden of Disease from Sharps Injuries to Health-Care Workers at National and Local Levels. World Health Organization: Geneva, 2005. (WHO Environmental Burden of Disease Series, No. 11). Available online: https:/ / www.who.int/quantifying ehimpacts / publications / ebd11.pdf?ua=1 (accessed on 31 October 2018).

10. Świątkowska, B.; Hanke, W.; Szeszenia-Dabrowska, N. Occupational Diseases in Poland in 2016; IMP: Lodz, Poland, 2017.

11. Karoney, M.J.; Kaumbuki, E.K.; Koech, M.K.; Lelei, L.K. Primary cutaneous tuberculosis in a 27-year-old medical intern from needle-stick injury: A case report. Clin. Case Rep. 2014, 3, 39-42. [CrossRef]

12. Jiang, L.; Ng, I.H.L.; Hou, Y.; Li, D.; Tan, L.W.L.; Ho, H.J.A.; Chen, M.I. Infectious disease transmission: Survey of contacts between hospital-based healthcare workers and working adults from the general population. J. Hosp. Infect. 2018, 98, 404-411. [CrossRef]

13. Ilhan, M.N.; Durukan, E.; Aras, E.; Türkçüoğlu, S.; Aygün, R. Long working hours increase the risk of sharp and needlestick injury in nurses: The need for new policy implication. J. Adv. Nurs. 2006, 56, 563-568. [CrossRef]

14. Ajzen, I. Martin Fishbein's legacy: The reasoned action approach. Ann. Am. Acad. Political Soc. Sci. 2012, 640, 11-27. [CrossRef]

15. Ajzen, I. The theory of planned behavior. Organ. Behav. Hum. Decis. Process. 1991, 50, 179-211. [CrossRef]

16. Kahneman, D. Thinking, Fast and Slow. Farrar, Straus and Giroux New York. 2011. Available online: http://codolc.com/books/Thinking,_Fast_and_Slow.pdf (accessed on 12 December 2018).

17. Wałaszek, M.; Kołpa, M.; Wolak, Z.; Różańska, A.; Wójkowska-Mach, J. Poor hand hygiene procedure compliance among polish medical students and physicians-The result of an ineffective education basis or the impact of organizational culture? Int. J. Environ. Res. Public Health 2017, 14, 1026. [CrossRef] 
18. Pruss-Ustun, A.; Rapiti, E.; Hutin, Y. Sharps Injuries: Global Burden of Disease from Sharps Injuries to Health-Care Workers. World Health Organization (WHO) Environmental Burden of Disease Series, No. 3; WHO Document Production Services: Geneva, Switzerland, 2003; ISBN 9241562463.

19. Garus-Pakowska, A.; Górajski, M.; Szatko, F. Awareness of the risk of exposure to infectious material and the behaviors of Polish paramedics with respect to the hazards from blood-borne pathogens-A nationwide study. Int. J. Environ. Res. Public Health 2017, 14, 843. [CrossRef]

20. Martins, A.; Coelho, A.C.; Vieira, M.; Matos, M.; Pinto, M.L. Age and years in practice as factors associated with needlestick and sharps injuries among health care workers in a Portuguese hospital. Accid. Anal. Prev. 2012, 47, 11-15. [CrossRef]

21. Gholami, A.; Borji, A.; Lotfabadi, P.; Asghari, A. Risk factors of needlestick and sharps injuries among healthcare workers. Int. J. Hosp. Res. 2013, 2, 31-38. Available online: http:/ /ijhr.iums.ac.ir/article_3875_ bfedf23c9fdfaada895808b0a365191c.pdf (accessed on 14 June 2018).

22. Sharma, S.; Gupta, A.; Arora, A. Knowledge, attitude and practices on needle-stick and sharps injuries in tertiary care cardiac hospital: A survey. Indian J. Med. Sci. 2010, 64, 396-401. [CrossRef]

23. Szczypta, A.; Różańska, A.; Bulanda, M. Analysis of occupational exposure of healthcare workers in the years 1998-2013 for bloodborne pathogens on the example of the hospital of the surgical profile. Med. Pracy 2014, 65, 723-732. [CrossRef]

24. Kocur, E.; Śliwa-Rak, B.; Grosicki, S. Analysis of cases of occupational exposure to blood recorded in the city hospital in Zabrze in 2006-2015. Przegl. Epidemiol. 2016, 70, 603-615. Available online: www.przeglepidemiol. pzh.gov.pl/pobierz-artykul?id=2120 (accessed on 17 December 2018).

25. Garus-Pakowska, A.; Górajski, M.; Szatko, F. Did legal regulations change the reporting frequency of sharp injuries of medical personnel? Study from 36 hospitals in Łódź Province, Poland. Int. J. Occup. Med. Environ. Health 2018, 31, 37-46. [CrossRef]

26. Gańczak, M.; Szczeniowski, A.; Jurewicz, A.; Karakiewicz, B.; Szych, Z. Model-based estimates of the risk of HCV transmission from infected patients to gynaecologic and obstetric Staff. Przegl. Epidemiol. 2012, 66, 437-443.

27. Salzer, H.J.F.; Hoenigl, M.; Kessler, H.H.; Stigler, F.L.; Raggam, R.B.; Rippel, K.E.; Langmann, H.; Sprenger, M.; Krause, R. Lack of risk-awareness and reporting behavior towards HIV infection through needlestick injury among European medical students. Int. J. Hyg. Environ. Health 2011, 214, 407-410. [CrossRef]

28. Motaarefi, H.; Mahmoudi, H.; Mohammadi, E.; Hasanpour-Dehkordi, A. Factors associated with needlestick injuries in health care occupations: A systematic review. J. Clin. Diagn. Res. 2016, 10, IE01-IE04. [CrossRef]

29. Bećirević, S.; Pranjić, N.; Sarajlić-Spahić, S.; Ahmetagić, S.; Huseinagić, S. Assessment of reporting, attitudes and knowledge about the stab incidents and professional risk of viral infection among health care professionals in primary health care. Mater. Soc. Med. 2013, 25, 113-117. [CrossRef]

30. Pavithran, V.K.; Murali, R.; Krishna, M.; Shamala, A.; Yalamalli, M.; Kumar, A.V. Knowledge, attitude, and practice of needle stick and sharps injuries among dental professionals of Bangalore, India. J. Int. Soc. Prev. Community Dent. 2015, 5, 406-412. [CrossRef]

31. Makary, M.A.; Al-Attar, A.; Holzmueller, C.G.; Sexton, J.B.; Syin, D.; Gilson, M.M.; Sulkowski, M.S.; Pronovost, P.J. Needlestick injuries among surgeons in training. N. Engl. J. Med. 2007, 356, 2693-2699. [CrossRef]

32. Cui, Z.; Zhu, J.; Zhang, X.; Wang, B.; Li, X. Sharp injuries: A cross-sectional study among health care workers in a provincial teaching hospital in China. Environ. Health Prev. Med. 2018, 23, 2. [CrossRef]

33. Jahangiri, M.; Rostamabadi, A.; Hoboubi, N.; Tadayon, N.; Soleimani, A. Needle stick injuries and their related safety measures among nurses in a University Hospital, Shiraz, Iran. Saf. Health Work. 2016, 7, 72-77. [CrossRef]

34. Rybacki, M.; Piekarska, A.; Wiszniewska, M.; Walusiak-Skorupa, J. Work safety among Polish health care workers in respect of exposure to bloodborne pathogens. Med. Pracy 2013, 64, 1-10. [CrossRef]

35. Lee, J.M.; Botteman, M.F.; Xanthakos, N.; Nicklasson, L. Needlestick injuries in the United States. Epidemiologic, economic, and quality of life issues. AAOHN J. 2005, 53, 117-133. [PubMed]

36. Jahic, R.; Piljic, D.; Porobic-Jahic, H.; Custović, A.; Petrovic, J.; Piljic, D. Epidemiological characteristics of the accidental exposures to blood-borne pathogens among workers in the hospital. Med. Arch. 2018, 72, 187-191. [CrossRef] [PubMed] 
37. Ishimaru, T.; Wada, K.; Hoang, H.T.X.; Bui, A.T.M.; Nguyen, H.D.; Le, H.; Smith, D.R. Nurses' willingness to care for patients infected with HIV or Hepatitis B/C in Vietnam. Environ. Health Prev. Med. 2017, $22,9$. [CrossRef] [PubMed]

38. Gańczak, M.; Szych, Z.; Szczeniowski, A.; Dmytrzyk-Danilów, G. Attitudes of medical specialists toward HBV, HCV or HIV infected surgical staff and a sero-survey among staff members. Med. Pracy 2013, 64, 639-647. [CrossRef] 